Dedicated to Prof. Hong-Kun Xu on the occasion of his $60^{\text {th }}$ anniversary

\title{
Modified inertial double Mann type iterative algorithm for a bivariate weakly nonexpansive operator
}

\author{
AnANtachai Padcharoen ${ }^{1}$ and KamonRat SOMbut ${ }^{2, *}$
}

\begin{abstract}
.
We introduce a modified inertial double Mann type iterative method to approximate coupled solutions of a bivariate nonexpansive operator $T: C \times C \rightarrow C$, where $C$ is a nonempty closed and convex subset of a Hilbert space. The one theorem and complement important old and recent results in coupled fixed point theory. Some appropriate examples to illustrate our results and their generalization are also given.
\end{abstract}

Acknowledgments. The first author thanks for the support of Rambhai Barni Rajabhat University. The authors thank you very much Prof. Vasile Berinde for his suggestions and comments. Finally, Kamonrat Sombut was financial supported by RMUTT annual government statement of expendture in 2019 and RMUTT Research Grant for New Scholar for fiscal year of 2019 (Grant no.NSF62D0603) was gratefully acknowledged.

\section{REFERENCES}

[1] Aghajani, A., Abbas, M. and Kallehbasti, E. P., Coupled fixed point theorems in partially ordered metric spaces and application, Math. Commun., 17 (2002), No. 2, 497-509

[2] Aghajani, A. and Arab, R., Fixed points of $(\psi, \varphi, \theta)$-contractive mappings in partially ordered b-metric spaces and application to quadratic integral equations, Fixed Point Theory Appl., 2013, 245 (2013), doi:10.1186/1687-1812-2013-245

[3] Amini-Harandi, A., Coupled and tripled fixed point theory in partially ordered metric spaces with application to initial value problem, Math. Comput. Model., 57 (2013), No. (9-10), 2343-2348

[4] Auslender, A., Teboulle, M. and Ben-Tiba, S., A logarithmic-quadratic proximal method for variational inequalities, Comput. Optim. Appl., 12 (1999), 31-40

[5] Bauschke, H. H. and Combettes, P. L., Convex Analysis and Monotone Operator Theory, in Hilbert Spaces (Springer, Berlin, 2011)

[6] Berinde, V., Khan, A. R. and Păcurar, M., Coupled solutions for a bivariate weakly nonexpansive operator by iterations, Fixed Point Theory Appl., 2014 (2014), Article ID 149

[7] Berinde, V., Coupled fixed point theorems for $\varphi$-contractive mixed monotone mappings in partially ordered metric spaces, Nonlinear Anal., 75 (2012), No. 6, 3218-3228

[8] Berinde, V. and Borcut, M., Tripled fixed point theorems for contractive type mappings in partially ordered metric spaces, Nonlinear Anal., 74 (2011), 4889-4897

[9] Berinde, V. and Păcurar, M., Coupled fixed point theorems for generalized symmetric Meir-Keeler contractions in ordered metric spaces, Fixed Point Theory Appl., 2012, 2012:115, 11 pp.

[10] Berzig, M. and Samet, B., An extension of coupled fixed point's concept in higher dimension and applications, Comput. Math. Appl., 63 (2012), No. 8, 1319-1334

Received: 29.05.2019; In revised form: 30.06.2019; Accepted: 14.07.2019

2010 Mathematics Subject Classification. 47H09, 47H10, $49 \mathrm{M} 05$.

Key words and phrases. Inertial Mann method, coupled solutions, bivariate nonexpansive and weekly nonexpansive.

Corresponding author: Kamonrat Sombut; kamonrat_s@rmutt.ac.th 
[11] Borcut, M. and Berinde, V., Tripled coincidence theorems for contractive type mappings in partially ordered metric spaces, Appl. Math. Comput., 218 (2012), No. 10, 5929-5936

[12] Border, K. C., Fixed point theorems with applications to economics and game theory, Cambridge University Press, New York (1985)

[13] Cataldo, A., Lee, E. A., Liu, X., Matsikoudis, E. D. and Zheng, H., A constructive fixed point theorem and the feedback semantics of timed systems, Technical Report UCB/EECS-2006-4, EECS Dept., University of California, Berkeley (2006)

[14] Ćirić, L., Damjanović, B., Jleli, M. and Samet, B., Coupled fixed point theorems for generalized Mizoguchi-Takahashi contractions with applications, Fixed Point Theory Appl., 2012, 2012:51, 13 pp., doi:10.1186/1687-1812-2012-51.

[15] Dong, Q. L. and Yuan, H. B., Accelerated Mann and CQ algorithms for finding a fixed point of a nonexpansive mapping, Fixed Point Theory Appl., 2015, 2015:125, 12 pp.

[16] Dong, Q. L., Yuan, H. B., Cho, Y. J., Rassias, Th. M., Modified inertial Mann algorithm and inertial CQalgorithm for nonexpansive mappings, Optim. Lett., 12 (2018), No. 1, 87-102

[17] Gu, F. and Yin, Y., A new common coupled fixed point theorem in generalized metric space and applications to integral equations Fixed Point Theory Appl., 2013, 2013:266, 16 pp. doi:10.1186/1687-1812-2013-266.

[18] Guo, Y., A generalization o Banach's contraction principle for some non-obviously contractive operators in a cone metric space, Turk. J. Math., 36 (2012), 297-304

[19] Halpern, B., Fixed points of nonexpanding maps, Bull. Amer. Math. Soc., 73 (1967), 957-961

[20] He, S. and Yang, C., Boundary point algorithms forminimum norm fixed points of nonexpansive mappings, Fixed Point Theroy Appl., 2014, 56 (2014)

[21] Hussain, N., Salimi, P. and Al-Mezel, S., Coupled fixed point results on quasi-Banach spaces with application to a system of integral equations, Fixed Point Theory Appl., 2013, 261 (2013), doi:10.1186/1687-1812-2013-261.

[22] Hyvärinen, A., Fast and robust fixed-point algorithms for independent component analysis, IEEE Transactions on Neural Networks, 10 (1999), No. 3, 626-634

[23] Ibn Dehaish, B. A., Khamsi, M. A. and Khan, A. R., Mann iteration process for asymptotic pointwise nonexpansive mappings in metric spaces, J. Math. Anal. Appl., 397 (2013), No. 2, 861-868

[24] Krasnoselskii, M. A., Two remarks on the method of successive approximations, Usp. Mat. Nauk., 10 (1955), 123-127

[25] Mann, W. R., Mean value methods in iteration, Proc. Am. Math. Soc., 4 (1953), 506-510

[26] Mainge, P. E., Convergence theorems for inertial KM-type algorithms, J. Comput. Appl. Math., 219 (2008), 223-236

[27] Mursaleen, M., Mohiuddine, S. A., Agarwal, R. P., Coupled fixed point theorems for $\alpha$ - $\psi$-contractive type mappings in partially ordered metric spaces, Fixed Point Theory Appl., 2012, 2012:228

[28] Nabil, T., Coupled fixed point of firmly nonexpansive mappings by Mann's iterative processes in Hilbert spaces, J. Comput. Anal. Appl., 27 (2019), 809-821

[29] Nocedal, J. and Wright, S. J., Numerical Optimization, 2nd edn. Springer Series in Operations Research and Financial Engineering (Springer, Berlin, 2006)

[30] Noumsi, A., Derrien, S. and Quinton, P., Acceleration of a content based image retrieval application on the RDISK cluster,In: IEEE International Parallel and Distributed Processing Symposium, April (2006)

[31] Olaoluwa, H., Olaleru, J. O and Chang, S. S., Coupled fixed point theorems for asymptotically nonexpansive mappings, Fixed Point Theory Appl., 2013, 68 (2013)

[32] Opial, Z., Weak convergence of the sequence of successive approximations for nonexpansive mappings, Bull. Amer. Soc., 73 (1967), 591-597

[33] Petryshyn, W. V., Construction of fixed points of demicompact mappings in Hilbert space, J. Math. Anal. Appl., 14 (1966) No. 2, 276-284

[34] Picard, E., Memoire sur la theorie des equations aux derivees partielles et la methode des approximations successives, J. Math. Pures et Appl., 6 (1890), 145-210

[35] Sang, Y., A class of $\varphi$-concave operators and applications, Fixed Point Theory Appl., 2013, 274 (2013), doi:10.1186/1687-1812-2013-274

[36] Samet, B., Vetro, C. and Vetro, P., Fixed point theorems for $\alpha$ - $\psi$-contractive type mappings, Nonlinear Anal., 75 (2012) No. 4, 2154-2165

[37] Sakurai, K. and Liduka, H., Acceleration of the Halpern algorithm to search for a fixed point of a nonexpansive mapping, Fixed Point Theory Appl., 2014, 202 (2014)

[38] Sintunavarat, W., Kumam, P., Cho, Y. J., Coupled fixed point theorems for nonlinear contractions without mixed monotone property Fixed Point Theory Appl., 2012, 170 (2012), doi:10.1186/1687-1812-2012-170 
[39] Yang, C. and He, S., General alternative regularization methods for nonexpansive mappings in Hilbert spaces, Fixed Point Theroy Appl., 2014, 203 (2014)

[40] Yantir, A. and Gulsan Topal, S., Positive solutions of nonlinear m-point BVP on time scale, Int. J. Difference Equ., 3 (2008), No. 1, 179-194

\author{
${ }^{1}$ Department of Mathematics, \\ FACULTy OF SCIENCE AND TECHNOLOGY \\ RAMBHAI BARNI RAJABHAT UNIVERSITY \\ CHANTHABURI 22000, THAILAND \\ Email address: anantachai.p@rbru.ca.th \\ ${ }^{2}$ Department of Mathematics And Computer SCiEnce, \\ DIVISION OF MATHEMATICS, \\ FACULTY OF SCIENCE AND TECHNOLOGY \\ RAJAMANGALA UNIVERSITY OF TECHNOLOGY THANYABURI (RMUTT), \\ THANYABURI, PATHUMTHANI 12110, THAILAND \\ Email address: kamonrat_s@rmutt.ac.th
}

